\section{RIMCIS}

\section{Hipatia Press}

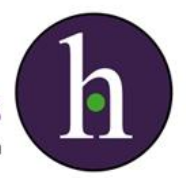

Instructions for authors, subscriptions and further details:

http://rimcis.hipatiapress.com

\title{
How Solidarity Influences Political Actors to Manage the Refugee Crisis: The Case of Proactiva Open Arms
}

Gemma Álvarez-Jiménez ${ }^{1}$, Maria Padrós-Cuxart ${ }^{1}$

1) Universidad de Barcelona, España

Date of publication: July $30^{\text {th }}, 2017$

Edition period: July 2017 - November 2017

To cite this article: Álvarez-Jiménez, G., \& Padrós-Cuxart, M. (2017). How Solidarity Influences Political Actors to Manage the Refugee Crisis: The Case of Proactiva Open Arms. International and Multidisciplinary Journal of Social Sciences, 6(2), 215-229. doi: 10.17583/rimcis.2017.2794

To link this article: http://doi.org/10.17583/rimcis.2017.2794

\section{PLEASE SCROLL DOWN FOR ARTICLE}

The terms and conditions of use are related to the Open Journal System and to Creative Commons Attribution License (CC-BY). 


\section{How Solidarity Influences Political Actors to Manage the Refugee Crisis: The Case of Proactiva Open Arms}

Gemma Álvarez-Jiménez

Universidad de Barcelona
Maria Padrós-Cuxart

Universidad de Barcelona

\section{Abstract}

Europe is facing the worst humanitarian crisis since World War II and the Mare Nostrum has become the path that millions of people are using to flee from the armed conflict, especially since the Syrian war began in March 2011. In this sense, according to the United Nations High Commissioner for Refugees (UNHCR), $1,014,973$ people arrived to Greece, Italy and Spain by sea in 2015 . Nevertheless, the Mediterranean area has become the scene of not only a humanitarian crisis but also citizens' solidarity. In this sense, Proactiva Open Arms, an NGO mostly formed by lifeguards, has helped 135,000 people to reach the coast safely, 10,273 of whom sailed in wandering boats. Of these individuals, 475 fell into the water and 9,067 were trapped on the cliffs. Proactiva Open Arms' work has driven European and Greek authorities to respond to refugees. In this paper, we analyse through this case how solidarity among civil citizens can change political actions and encourage other citizens to act in solidarity, as part of the H2020 European funded research project SOLIDUS

Keywords: solidarity, refugee crisis, social impact, human rights, citizen's initiative 


\section{Cómo Influye la Solidaridad en los Actores Políticos que Gestionan la Crisis de los Refugiados: El Caso de Proactiva Open Arms}

Gemma Álvarez-Jiménez Universidad de Barcelona
Maria Padrós-Cuxart

Universidad de Barcelona

\section{Resumen}

Europa se enfrenta a la peor crisis humanitaria desde la Segunda Guerra Mundial y el Mar Mediterráneo se ha convertido en el camino que millones de personas están utilizando para huir del conflicto armado, especialmente desde que la guerra siria comenzase en marzo de 2011. En este sentido y según el Alto Comisionado de las Naciones Unidas para los Refugiados (ACNUR), 1.014.973 personas llegaron a Grecia, Italia y España por la vía marítima en 2015. Sin embargo, el área del Mediterráneo no sólo se ha convertido en el escenario de una crisis humanitaria, sino también de la solidaridad ciudadana. En este sentido, Proactiva Open Arms, una ONG formada en su mayoría por socorristas, ha ayudado a 135.000 personas a llegar a la costa de manera segura, 10.273 de los cuales navegaron en botes errantes. De estos individuos, 475 cayeron en el agua y 9,067 estaban atrapados en acantilados. El trabajo de Proactiva Open Arms ha llevado a las autoridades europeas y griegas a intensificar su respuesta ante los refugiados. En este trabajo analizamos a través de este caso cómo la solidaridad entre los ciudadanos civiles puede cambiar las acciones políticas y animar a otros ciudadanos a actuar solidariamente, como parte del proyecto de investigación financiado por fondos europeos H2020 SOLIDUS.

Palabras clave: solidaridad, crisis de refugiados, impacto social, derechos humanos, iniciativas ciudadanas

2017 Hipatia Press

ISSN: 2014-3680

DOI: $10.17583 /$ rimcis.2017.2794 


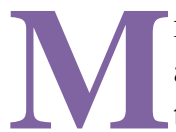

illions of people are fleeing from armed conflicts in Syria, Iraq and Afghanistan as well as other countries. Solely as a result of the Syrian civil war, according to the United Nations High Commissioner for Refugees (hereafter UNHCR) (2016a), 4,843,344 people have become refugees since its start in March 2011. Thus, trying to find shelter, refugees have moved to neighbouring countries such as Lebanon (1,048,275 refugees), Jordan (655,217 refugees), Iraq (246,589 refugees), Egypt (120,491 refugees) and Turkey (2,743,476 refugees), which are bearing the brunt of this humanitarian crisis and taking in the largest number of refugees (UNHCR, 2016a). However, Europe has also been affected by this migration crisis. Many refuges, attracted by the idea of safety in Europe, have started a long journey through land and sea routes with the aim of finding a safe place to rebuild their lives. According to UNHCR (2016b), $1,014,973$ people arrived to Greece, Italy and Spain by sea in 2015. The right to asylum is crucial for their salvation (Mautz, 2015). Thus, according to the Red Cross (2016), from January 2015 to June 2016, 1,221,277 refugees arrived in Europe, primarily through Greece and Italy. The sea route has become more important, especially given that some countries in the European Union started to block the land routes. One of the points of arrival of refugees prior to the EU-Turkish Agreement in March 2016 (Council of the European Union, 2016; European Commission, 2016) was Lesbos Island. This small Greek island is located $9 \mathrm{~km}$ off the coast of Turkey and it mainly dedicated to tourism. Its 85,000 inhabitants have been affected by the arrival of migrants and refugees since the summer of 2015 (Spanish Commission for Refugee Aid, 2016, p. 3). According to the Spanish Commission for Refugee Aid (2016), approximately 500,000 refugees arrived in Lesbos in 2015, particularly from the northeast region of Canakkale.

In this sense, also according to the Spanish Commission for Refugee Aid (2016), the Turkey-Lesbos routes started when refugees arrived at Istanbul and made their first contact with the traffickers in Taksim Square. The traffickers offered wealthy refugees a false passport and flights to reach Europe. However, those who could not afford to pay for a false passport and plane ticket were pushed to reach Europe via the Aegean Sea. As a result, these refugees went to the coastal city of Izmir, where traffickers received 


\section{8 Álvarez-Jiménez \& Padrós-Cuxart-Proactiva Open Arms}

them in Basmane Square. When the refugees arrived at that square, the traffickers took them to hostels in which they were hidden for approximately two weeks until they were transported by van to the point at which the boats sailed to Lesbos. The refugees paid approximately 1,000 to 2,000 euros per person to get onto the boats, according to Proactiva Open Arms. Although the traffickers offered them a false life vest without any safety guarantee, the refugees had to pay anyway. Thus, they began a dangerous journey on which many people lost their life. According to the Missing Migrants Project (IOM, 2016), 2,920 of them disappeared or died. According to the Red Cross (2016), the number is 2,856.

Given this situation, a group of volunteers, most of whom were professional lifeguards, who were members of the NGO Proactiva Open Arms, helped 135,000 people to reach the coast safely, 10,273 of whom had sailed in wandering boats. Of these individuals, 475 of whom had fallen into the water and 9,067 of whom were trapped on cliffs (these data was provided by Proactiva Open Arms showed in Clam Festival, 2016). These volunteers risked their own life to save many parents, children and elderly people who struggled to save the only thing that they had: their life. As a result, the European Parliament gave them the award for European Citizen's 2016 to recognise the impact of their caring work in Lesbos (European Parliament Affairs, 2016).

The social impact achieved by this NGO, mainly in terms of saving people's lives, but also in raising awareness among citizens and authorities (see Proactiva Open Arms website) about the alarming situation in the Mediterranean, and actually engaging them into action, motivated the SOLIDUS "SOLIDUS. Solidarity in European Societies: Empowerment, Social Justice and Citizenship"- funded by the European Commission under the Horizon 2020 Programme- to study this case further in depth. The objective of SOLIDUS is to analyse actions of solidarity in Europe in times of crisis that have achieved social improvements in order to inform public policy. 


\section{Data Collection \& Analysis}

The case study of Proactiva Open Arms was carried out through documental analysis of online information about this NGO, database from other organizations involve with refugees and press. Particularly, press is one of the most relevant communication channels of Proactiva Open Arms and this is the reason because we have collected it. Parallel, we have carried out qualitative interviews (two) with the goal of obtaining deeper information of the NGO Proactiva Open Arms. Given that Proactiva Open Arms team changes regularly, we selected two interviewers who were involved in the rescue of refugees since the beginning of the formation of this NGO until now. The interviews were made in May 2016. All of the names and personal information have been carefully treated and only used for the purpose of this article and SOLIDUS project, according to the agreement that was established by both parties involved. In addition, all real names have been anonymized and fictitious names have been created.

Table 1.

Interviews profiles

\begin{tabular}{lll}
\hline Interview & Gender & Profession
\end{tabular}

\begin{tabular}{lll}
\hline E1. Oriol & Male & $\begin{array}{l}\text { Lifeguard (Proactiva } \\
\text { Open Arms member) }\end{array}$ \\
E2. Jordi & Male & $\begin{array}{l}\text { Lifeguard (Proactiva } \\
\text { Open Arms member) }\end{array}$ \\
\hline
\end{tabular}

\section{Data analysis}

Documentary analysis and the (two) in-depth interviews has been analysed through biography technique. This technique have achieved great scientific relevance in qualitative research (Denzin, 1989, 2006; Denzin \& Lincoln, 2005). Concretely, we have made a biography of the NGO Proactiva Open 
Arms, remarking these situations where their solidarity action have transformed political actions and it has encouraged citizens' solidarity.

\section{Proactiva Open Arms Shows How Solidarity Can Transform Political Actions and Encourage Citizens' Solidarity}

The solidarity action of Proactiva Open Arms started when two lifeguard of Badalona (a municipality of Catalonia), who worked in a marine services company specializing in aquatic safety called Pro-Activa Servicios Acuáticos [Pro-Activa Water Services], decided to go to the island of Lesbos as a volunteers to help refugees. Thus, they arrived to the island of Lesbos in September 2015 with $€ 15,000$ to help refugees for a month (Pérez, 2016). In that time, Greece was overwhelmed by the situation (Kousoulis, IoakeimIoannidou \& Economopoulos, 2016), especially the island of Lesbos. The refugees' arrivals had increased exponentially (see figure 1), only in September 89, 690 refugees reached the island.

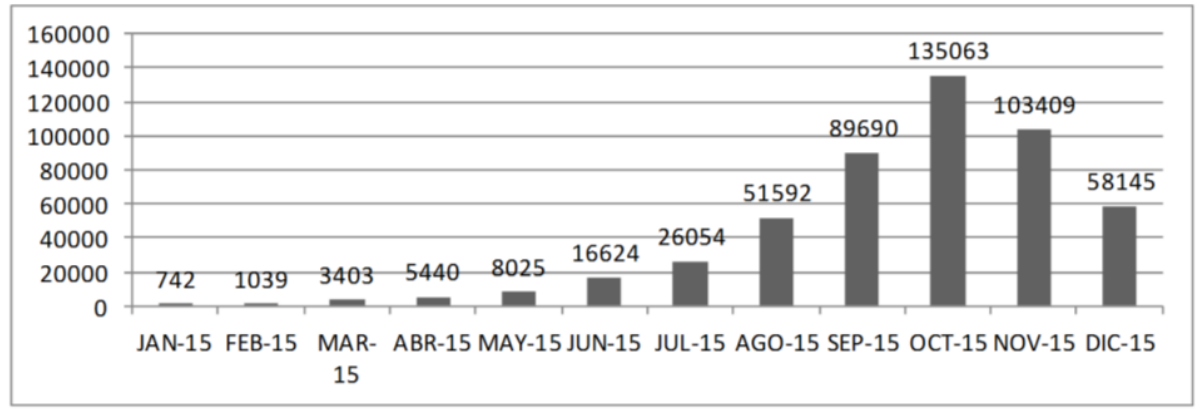

Source: UNHCR, 2015

Figure 1. Lesbos arrivals per month

Despite the hundreds of arrivals, no large NGO was receiving refugees on the coast. Only private citizens went there voluntarily to welcome refugees. Citizens are often the first to mobilise in crisis situations (Ataç, Rygiel \& Stierl, 2016; Hein \& Niazi, 2016). When the two lifeguard volunteers arrived and observed the situation with their own eyes, they were shocked. Many refugees drowned before reaching the shore because their 
boat sank due to overloading. No one, including the volunteers on the coast, swam to rescue the people who were sinking in the sea a few metres from the coast. Given the situation, the two lifeguard volunteers jumped into the seawater clothed to start to save people. However, instead of helping them, other volunteers started to shout at them. This situation was explained by one of the volunteers: "[other] volunteers, people like you and me who were as concerned as us, shouted at us saying that it was dangerous, what we were doing" (Oriol, Proactiva Open Arms member). Thus, instead of being supported and assisted by the rest of the volunteers, the two lifeguard volunteers were viewed as "crazy people"; however, they continued risking their lives to save others'. This is an example of how voluntary initiatives within solidarity movements can create barriers that impede the promotion of greater caring and improve their actions. In this sense, the question regarding why there are barriers within solidarity movements is interesting. One hypothesis could be that within these solidarity movements, the initial objective of their actions sometimes is forgotten, as the urgent focus on everyday tasks exceeds them. Thus, when an external initiative introduces a new method or means to achieve the objective, they not assess the effectiveness of the action in relation to the objective. Whereas this could be the case of the rest of the volunteers in relation to the Pro-Activa volunteers, deeper scientific analysis is necessary. In the case that is analysed in this paper, the Pro-Activa volunteers had a clear objective: to defend the right to life, the first law of human rights. Thus, Pro-Activa volunteers, despite this lack of caring and support from other volunteers who were on the coast, decided to wear lifeguard uniforms and continue to save lives. They decided to wear the uniform to show that they were professionals; therefore, they legitimised their job.

As a result of their work, they became indispensable to the island and obtained the support of the rest of volunteers. Thus, one of the volunteers explained, "Volunteers asked us for our phone and, when something occurred somewhere, they called us" (Jordi, Proactiva Open Arms member). However, a few months later the two volunteers of Pro-Activa run out their $€ 15,000$. In this situation, they decided to create a NGO, namely Proactiva Open Arms, and started a "crowdfunding" initiative. As a consequence of Proactiva Open Arms work on the island, they deserved the international 


\section{2 Álvarez-Jiménez \& Padrós-Cuxart-Proactiva Open Arms}

media's attention. This international media's attention allowed that crowdfunding initiative increased their resources exponentially. Thus, they increased their human resources, growing to 18 volunteers who rotated every 15 days in the period of maximum activity. In the beginning, they only had their personal equipment (neoprene suits, rubber rings, etc.). However, a few months later, they managed to obtain two cars, jet skis and three rescue boats. As it mentioned above, they started with a budget of $€ 15,000$ in 2015 but in 2016, up to September 30th, contributions reached 2.1 million euros (Proactiva Open Arms, 2016).

Additionally, they became indispensable to the Greece Authorities and Frontex as well, which originally did not coordinate with them or any other NGOs that were taking action on the island. As a consequence of the magnitude of the tragedy, political authorities started to contact them. In this sense, the night of October 28, 2015 is remembered as one of the worst nights at Lesbos Island. An old wooden boat that was in poor condition (the ship's hull was rotten) and overloaded, with three hundred people aboard approximately, broke and began to sink near the coast of Lesbos. At that time, NGO Proactiva Open Arms had 4 volunteers and only two jet skis for rescuing purposes. When they arrived at the wreck, they observed many people in the sea who were trying to save their lives. Some of them had died, and their bodies were floating in the sea. There were children, pregnant women, teenagers, men and women on board. Children and pregnant women were the most vulnerable groups on the boat. Typically, women and children cannot swim, so they are normally in a much worse situation than the rest of the group. Their situation were even worse than that of the others' due to the heavy wet clothes they wore that made them drown quickly.

Proactiva Open Arms was trying to save as many people as possible, but they soon realised that they needed help to overcome this situation. They could not cope with everything that was needed in this humanitarian crisis. Then, Frontex authorities went to the location to help refugees. However, Frontex's assistance was not as useful as expected. Frontex brought a large boat that was not equipped for rescuing services; it was designed for monitoring tasks. The boat had very high sides, making it difficult for the rescued refugees to get on board. In addition, the ship did not have medical services, and the Frontex professionals who were on the boat did not have 
enough knowledge to complete resuscitation tasks, according to Proactiva Open Arms. Given this lack of resources and knowledge, some Proactiva volunteers boarded the boat to save refugees and carry out resuscitation tasks (Diez \& Fontseca, 2016). At the same time, the task of the Greek Coastguard was also insufficient to address the tragedy. Thus, a group of Greek fishermen took their boats, that they used to perform their daily fishing activities, to rescue refugees. Finally, according to Proactiva Open Arms, approximately two hundred people were rescued, whereas many died, including mothers who left orphaned children. Proactiva Open Arms received the Honouring Excellence in Rescue Operations (HERO) award from the International Maritime Rescue Federation for their humanitarian work on October 28, 2015 (La Vanguardia, 2016). Parallel, two Greece volunteers, who also helped refugees, were nominated for the Nobel Peace Prize in 2016 (Schoenbauer, 2016).

The night of October 28, 2015 was not the only night in which Frontex or Greece authorities had to intervene. Nevertheless, it represented a turning point in the response by political authorities, especially Frontex and the Greece Coastguard. Since then, these authorities started to collaborate more intensely with the rest of the NGOs that were operating in Lesbos and performed rescue tasks in emergency situations. This change in response was a consequence of the example shown by Proactiva Open Arms. In this sense, one of the volunteers said, "When the Coastguard, Frontex and the UN overstated it, our presence humanised them" and added that "our presence forced them to act [...] even the Greek press reported that Proactiva Open Arms is humanising the Greece Coastguard. Our presence there made them work a little more, because we recorded them with cameras, and they knew it. Being internationally recognised, they could not avoid it" (Oriol, Proactiva Open Arms member). This is an example of how solidarity forces authorities to perform in a refugee crisis. The task of Proactiva Open Arms in Lesbos was widespread through several mass media outlets from Spain, Greece and even in the United States. The following headline was included in The New York Times: "As More Children Drowned, Volunteers on Lesbos Say Rescues Are Left Largely to Them" (Mackey, 2015).

After the EU-Turkey agreement in March 2016, the influx of refugees to the island of Lesbos decreased drastically. Thus, a volunteer said that 


\section{4 Álvarez-Jiménez \& Padrós-Cuxart-Proactiva Open Arms}

"arrivals are testimonial" (Jordi, Proactiva Open Arms member). However, this decrease in the number of refugees on the coast of Lesbos did not mean that refugees stopped trying to reach Europe. New routes through the Mediterranean emerged. Thus, North African routes became prevalent since March 2016, and traffickers continued their filthy commerce with refugees. The volunteers of Proactiva Open Arms, who was aware of this situation, continued to maintain solidarity with refugees. In this sense, in summer of 2016, they started to operate with a large boat called "Astral", which was donated by a multimillionaire for rescuing refugees in the area of Lampedusa. The boat was object of a remodelling. Thus, volunteers of Proactiva Open Arms worked hard to convert a luxury boat to a rescue boat in order to help refugees in the middle of the Mediterranean sea. Thus, volunteers made task of remodeling such as eliminate luxury objects, incorporate a cabin-infirmary, equip technology and improve communication systems to be able to collaborate with other organizations in the sea (Arias \& Palacios, 2016). Finally, in the mid-June 2016, the boat "Astral" sailed to the central Mediterranean in order to save more refugees (E1 Periódico, 2016). Since then, a team of volunteers formed by doctors, ship captain and lifeguards have been rescuing day and night hundreds of refugees. Only three months later, Proactiva Open Arms had already saved 12,500 refugees on the route of the central Mediterranean (Arias \& Palacios, 2016).

However, Proactiva Open Arms was mindful that the sailboat "Astral" was insufficient to save the refugees and brought them to the coast of Italy, thus they achieved a new bigger boat thanks to the solidarity of Grupo Ibaizabal, which is a commercial organisation involved primarily in the ship management. The boat donated by Grupo Ibaizabal was built in 1974 and it is a tugboat of $37 \mathrm{~m}$ length. That boat belonged to the Spanish Maritime Rescue Fleet along years. Now, it has been renamed as "Open Arms" tugboat. Such as the "Astral", this tugboat also has been remodeled in order to incorporate all the necessary tools to make humanitarian surveillance and rescuing tasks. In this new boat, there are 6 crew and more voluntaries. The tugboat has capacity to harbor 400 people and sailed away the summer of 2017. 
Proactiva Open Arms still saving the lives of refugees from the sea. Their labor started in September of 2015 from the solidarity of two lifeguards who decided to go to Lesbos with their own resources in order to help refugees. Thanks to the solidarity of other citizens, they have been able to continue their rescue work and increasing their infrastructures. Therefore, speaking of refugees supposes speaking about solidarity of some citizens.

\section{Conclusions}

The refugee crisis is a challenge that Europe and other political powers have to resolve. The response of Europe to this issue has not been effective. Scholars have analysed this situation (Jeandesboz \& Pallister-Wilkins, 2016; Pallister-Wilkins, 2016; Perkowski, 2016; Van Reekum, 2016) and they have remarked the humanitarian consequences of the refugee crisis and law implications of this phenomenon.

However, the critical reality has allowed for the outbreak of multiple caring initiatives with a high social impact (Flecha, Soler-Gallart \& Sordé, 2015). In this sense, the social impact of the action by Proactiva Open Arms is indisputable. Consequently, Proactiva Open Arms has been awarded different prizes. In addition, the Proactiva Open Arms case is a clear example of how solidarity with a high social impact drives a highly transformative process. Before the two Proactiva volunteers arrived in Lesbos, volunteers were leading different initiatives to help refugees but their social impacts were not so high. Nevertheless, the high number of lives which were saved by Proactiva Open Arms changed the responses of Frontex and the Greek Coastguard. Simultaneously, Proactiva Open Arms became a benchmark for other volunteers and NGOs on the island.

In parallel, the case of Proactiva Open Arms has allowed researchers to consider the concept of solidarity. Given that the term solidarity has been a versatile concept over the years and has been the subject of various reformulations both doctrinally and ideologically, the case of Proactiva Open Arms shows a new dimension of solidarity. When it is based on the defence of human rights, solidarity has a social impact and can transform political actions towards a solution to complex problems. Thus, the action of citizens such as the Proactiva Open Arms volunteers allows for a quicker response to 
social demands, producing empowerment of citizens that leads to community policy and influences institutions to change their actions or even forces them to act. In some situations, political authorities are slow due to bureaucratic procedures, complex partisan negotiations and regulations that hinder a rapid response to social problems. In this sense, citizen solidarity becomes a powerful alternative tool. Additionally, collaboration and dialogue between civil society and institutions is essential to manage this humanitarian crisis.

Finally, we must note that solidarity is usually under-examined when a conflict is analysed. However, the refugee crisis shows that solidarity movements that arise from people's empowerment also appear in critical situations. In future studies, it will be interesting to study the reason why some social movements have a high social impact and transform political actions, whereas others do not and why there are barriers within solidarity movements that could have negative results in the ever-increasing social impact of their intervention.

\section{Acknowledgements}

The research SOLIDUS leading to these results received funding from the H2020 Programme of the European Commission under Grant Agreement n 649489.

\section{References}

Arias, M., \& Palacios, S. (2016, September 26). 'Astral', un velero de lujo al rescate de refugiados. El Mundo. Retrieved from http://www.elmundo.es/internacional/2016/09/26/57e8024e22601d02 748b458f.html

Ataç, I., Rygiel, K., \& Stierl, M. (2016). Introduction: The Contentious Politics of Refugee and Migrant Protest and Solidarity Movements: Remaking Citizenship from the Margins. Citizenship Studies 20(5), 527-544. doi: 10.1080/13621025.2016.1182681

Clam Festival (2016). La oenegé proactiva open arms rep el premi pere casaldàliga a la solidaritat 2016. Retrieved from 
http://clamfestival.org/2016/05/la-oenege-proactiva-open-arms-rep-elpremi-pere-casaldaliga-a-la-solidaritat-2016/

Council of the European Union (2016). EU-Turkey Statement. 18 March, 2016. Press Release 144/16, 18/03/2106. Retrieved from http://www.consilium.europa.eu/press-releasespdf/2016/3/40802210113_en.pdf

Denzin, N.K. (1989). Interpretive biography. Thousand Oaks, CA: SAGE.

Denzin, N.K. (2006). Analytic autoethnography or Déjà Vu all over again. Journal of Contemporary Ethnography, 35, 419- 428. doi: 10.1177/0891241606286985

Denzin, N.K., \& Lincoln, Y.S. (Eds.). (2005). The SAGE handbook of qualitative research (3rd ed.). London, England: SAGE.

Diez, A., \& Fontseca, D. (2016). To Kyma. Rescat al mar Egeu [Video file]. Retrieved from http://www.ccma.cat/tv3/alacarta/sense-ficcio/tokyma-rescat-al-mar-egeu/video/5579941

El Periódico (2016, June 17). Proactiva Open Arms extiende su labor de rescate de refugiados al Mediterráneo central. El Periódico. Retrieved from http://www.elperiodico.com/es/noticias/internacional/proactivaopen-arms-extiende-labor-rescate-refugiados-mediterraneo-central5212805

European Commission (2016). Implementing the EU-Turkey Agreement Questions and Answers. European Commission Fact Sheet, MEMO 16/1221. Retrieved from http://europa.eu/rapid/press-release_MEMO16-1221_en.htm

European Parliament Affairs (2016, June 3). European Citizen's Prize: 50 people and organisations honoured. News European Parliament. Retrieved from http://www.europarl.europa.eu/resources/library/media/20160603RES 30254/20160603RES30254.pdf

Flecha, R., Soler-Gallart, M., \& Sordé, T. (2015) Social impact: Europe must fund social sciences. Nature, 528, 193. doi: 10.1038/528193d

Hein, J., \& Niazi, T. (2016). The primordial refugees: Religious traditions, global forced migration, and state-society relations. International Sociology, 31(6), 726-741. doi: 10.1177/0268580916662388 
International Organization for Migration (IOM) (2016). Missing Migrants Project Database. Retrieved from International Organization for

Migration website: http://missingmigrants.iom.int

Jeandesboz, J., \& Pallister-Wilkins, P. (2016). Crisis, Routine,

Consolidation: The Politics of the Mediterranean Migration Crisis.

Mediterranean Politics, 21(2), 316-320. doi:

10.1080/13629395.2016.1145825

Kousoulis, A.A., Ioakeim-Ioannidou, M., \& Economopoulos, K.P. (2016). Refugee crisis in Greece: not a one-country job. International Journal of Public Health, 67(1), 1-2. doi: 10.1007/s00038-016-0890-0

La Vanguardia (2016, November 16). Proactiva Open Arms recibe un premio por su labor de rescate marítimo. La Vanguardia. Retrieved from

http://www.lavanguardia.com/vida/20161116/411918050157/proactiv a-open-arms-recibe-un-premio-por-su-labor-de-rescate-maritimo.html

Mackey, R. (2015, October 29). As More Children Drown, Volunteers on Lesbos Say Rescues Are Left Largely to Them. New York Times. Retrieved from http://www.nytimes.com/2015/10/30/world/europe/asmore-children-drown-volunteers-on-greek-island-say-rescues-are-leftlargely-to-them.html?_r=0

Mautz, Ch. (2015). The Refugee in Europe. International and Multidisciplinary Journal of Social Sciences, 4(3), 293-311. doi: 10.17583/rimcis.2015.1803

Pallister-Wilkins, P. (2016). Interrogating the Mediterranean 'Migration Crisis'. Mediterranean Politics, 21(2), 311-315. doi: 10.1080/13629395.2016.1145826

Pérez, B. (2016, March 17). El socorrista de Badalona que salva vidas en el Egeo. $\quad$ El Periódico. $\quad$ Retrieved from http://www.elperiodico.com/es/noticias/sociedad/catala-de-any-oscarcamps-proactiva-open-arms-salva-vidas-refugiados-egeo-4954352

Perkowski, N. (2016). Deaths, Interventions, Humanitarianism and Human Rights in the Mediterranean 'Migration Crisis'. Mediterranean Politics, 21(2), 331-335. doi: 10.1080/13629395.2016.1145827

Proactiva Open Arms (2016). Proactiva Open Arms. Retrieved from https://www.proactivaopenarms.org 
Red Cross (2016). Crisis de refugiados en Europa. Informe situación $n^{\circ} 12$. Retrieved from Red Cross website: http://www.cruzroja.es/cre_web/principalci/assets/iscrisisrefugiados_1 2.pdf

Schoenbauer, R. (2016, October 7). Volunteers who saved lives on Lesvos nominated for Nobel Peace Prize. UNHCR News. Retrieved from http://www.unhcr.org/news/latest/2016/10/57f7732d4/volunteerssaved-lives-lesvos-nominated-nobel-peace-prize.html

Spanish Commission for Refugee Aid (2016). Lesbos, 'zona cero' del derecho de asilo. Retrieved from Spanish Commission for Refugee Aid website: http://www.cear.es/wpcontent/uploads/2016/04/Informe-Mision-Lesbos-marzo2016.pdf

UNHCR (2015). Lesvos island snapshot - 30 Dec 2015. Retrieved from UNHCR Data Portal website: http://reliefweb.int/report/greece/greece-lesvos-island-snapshot-30dec-2015

UNHCR (2016a). Syria Regional Refugee Response. Inter-agency Information Sharing Portal. Retrieved from UNHCR Data Portal website http://data.unhcr.org/syrianrefugees/regional.php

UNHCR (2016b). Refugees \& migrants sea arrivals in Europe. Monthly data update: December 2016. Retrieved from UNHCR Data Portal website http://reliefweb.int/sites/reliefweb.int/files/resources/Monthly_Arrival S_to_Greece_Italy_Spain_Jan_Dec_2016.pdf

Van Reekum, R. (2016). The Mediterranean: Migration Corridor, Border Spectacle, Ethical Landscape. Mediterranean Politics, 21(2), 336-441. doi: 10.1080/13629395.2016.1145828

Gemma Álvarez-Jiménez is PhD candidate in Political Science at the Department of Sociology at the University of Barcelona, Spain

Maria Padrós-Cuxart is associate professor in the Department of Didactics and Educational Organization at the University of Barcelona, Spain

Contact address: Diagonal Nord, Facultat d'Economia i Empresa (Edifici 690). Diagonal 690, 08034, Barcelona. Spain. Email: gemma.alvarez@ub.edu 